\title{
Effects of organic carbon and UV wavelength on the formation of dissolved gaseous mercury in water under a controlled environment
}

\author{
Jae-In Lee ${ }^{1}$, Ji-Hye Yang ${ }^{2}$, Pyung-Rae Kim¹, Young-Ji Han ${ }^{1}$ \\ ${ }^{1}$ Department of Environmental Science, Kangwon National University, Chuncheon 24341, Republic of Korea \\ ${ }^{2}$ Policy Planning Team, AKA Inc., Seoul 08052, Republic of Korea
}

\begin{abstract}
The effects of UV wavelength and dissolved organic carbon (DOC) on the formation of dissolved gaseous mercury (DGM) were investigated in a controlled environment. To remove any other influences than UV wavelength and DOC, purified water was used as the working solution. DGM was instantly produced with irradiation of all UV lights even without DOC; whereas, there was no noticeable increase of DGM during irradiation of visible light. The amount of formed DGM increased as the DOC concentration increased even in dark conditions; however, UV-B irradiation significantly promoted DGM production with DOC present. The rate constants of reduction ranged from 1.4 $\times 10^{-6} \mathrm{~s}^{-1}$ to $3.5 \times 10^{-5} \mathrm{~s}^{-1}$, with the lower values occurring under the dark condition without DOC and the higher values resulting under UV-B irradiation and high DOC concentration. However, DGM production was not linearly correlated with the DOC concentration at higher range of DOC in this study. Future studies should investigate the effects of DOC concentration on mercury (Hg) reduction over the broad range of DOC concentrations with different DOC structures and with other influencing parameters.
\end{abstract}

Keywords: Dissolved gaseous mercury, Dissolved organic carbon, Mercury reduction, UV wavelength

\section{Introduction}

Mercury (Hg) differs from other heavy metals because it can exist as gas and consequently can cycle between various environmental media. Atmospheric Hg mostly exists as inorganic forms; however, once it is deposited into water and soil surfaces, it can be converted to methyl $\mathrm{Hg}$, which is the most toxic form, mainly by anaerobic bacteria in aquatic and/or terrestrial ecosystems [1-4]. Methyl $\mathrm{Hg}$ is then bio-magnified through the food chain and hence effectively accumulating in carnivorous fish and humans. Atmospheric Hg sources are typically classified as anthropogenic sources, natural sources, or re-emissions of $\mathrm{Hg}$ which was previously deposited on surfaces. According to the United Nations Environment Programme [5], two-thirds of the total global $\mathrm{Hg}$ emissions is produced from natural surfaces including aquatic and soil surfaces. In an aquatic system, Hg mainly exists as divalent forms and either in dissolved or particulate forms as inorganic and organic complexes [6-8]. Divalent Hg can be reduced through biotic and abiotic processes to elemental $\mathrm{Hg}\left(\mathrm{Hg}^{0}\right)$, the dominant form of dissolved gaseous mercury (DGM). Since $\mathrm{Hg}^{0}$ has a high vapor pressure and low Henry's Law constant [9], DGM is assumed to be readily volatilized to the atmosphere once it is formed on a water surface. Therefore, the reduction process is highly important for the removal pathway of $\mathrm{Hg}$ pools in an aquatic ecosystem while it is connected to the significant input to the atmospheric Hg pool.

Divalent $\mathrm{Hg}$ can be reduced either via biotic processes by small-size phytoplankton or bacteria and via abiotic processes [10-17]. Abiotic reduction is regarded to be more important than biotic processes especially in surface water. Many previous studies have suggested that solar radiation was the most important factor for abiotic reduction mechanisms; therefore, DGM formation typically follows a same diel pattern of solar radiation, which results in a high formation rate at midday and low formation rate at night
This is an Open Access article distributed under the terms of the Creative Commons Attribution Non-Commercial License (http://creativecommons.org/licenses/by-nc/3.0/) which permits unrestricted non-commercial use, distribution, and reproduction in any medium, provided the original work is properly cited.

Copyright (C) 2019 Korean Society of Environmental Engineers
Received January 23, 2018 Accepted May 22, 2018

${ }^{\dagger}$ Corresponding author

Email: youngji@kangwon.ac.kr

Tel: +82-33-250-8579 Fax: +82-33-259-5563

ORCID: 0000-0002-1060-5084 
[18-21]. UV lights are considered more effective on DGM formation than visible light [22]. However, other studies observed irregular diel fluctuations of DGM concentration [10, 23], which indicates that other factors in addition to solar radiation must be influencing the oxidation-reduction of Hg. Dissolved organic carbon (DOC) concentrations are also acknowledged to be an important factor for Hg reduction. Most studies found that DGM concentrations clearly increased with the presence of DOC [14, 20-22, 24-25]. At the same time, other studies have demonstrated that an increasing DOC concentration caused a decrease in the ratio of DGM to total mercury [26], possibly because high DOC concentrations result in the enhanced stability of $\mathrm{Hg}(\mathrm{II})$ complexes with DOC [27] or DOC caused attenuation of solar radiation [28-30]. On the other hand, some studies showed the interacting effects of DOC and solar radiation. Allard and Arsenie [31] suggested that $\mathrm{Hg}(\mathrm{II})$ must be complexed with DOC for photoreduction to occur.

Most previous studies tracked the relationship between DGM concentration and various environmental parameters in the natural environment to identify the influencing factors on $\mathrm{Hg}$ reduction. However, reduction and oxidation always occurs concurrently in natural environments, making it difficult to identify the sole effect of the parameters on $\mathrm{Hg}$ reduction or $\mathrm{Hg}$ oxidation. In addition, it is difficult to interpret the DGM formation that results from a single parameter because parameters unpredictably interact with each other in the natural environment.

In this study, DGM production was continuously tracked in a controlled environment to identify the individual and combined effects of the two most important parameters influencing DGM formation: the wavelength of light and DOC concentration. Purified water was used in this study because multitudinous parameters that are not identified or considered in experiments can unpredictably interact with each other in lake or ocean sample.

\section{Methods}

\subsection{Experimental Design}

\subsubsection{Working solutions}

Since the total $\mathrm{Hg}$ concentrations are typically found in the range of 0.5 to $10 \mathrm{ng} \mathrm{L}^{-1}$ in most of lakes [14, 23, 32], the working solutions containing $1 \mathrm{ng} \mathrm{L}^{-1}$ and $10 \mathrm{ng} \mathrm{L}^{-1}$ of $\mathrm{Hg}$ were prepared from a $100 \mathrm{ppm}$ stock $\mathrm{Hg}\left(\mathrm{NO}_{3}\right)_{2}$ (SPEX CertiPrep, preserved with $5 \% \mathrm{HNO}_{3}$ ) in this study. A $0.5 \mathrm{~mL}$ of $100 \mathrm{ppm}$ standard solution was added to a $50 \mathrm{~mL}$ glass tube filled with $10 \mathrm{~mL}$ of ultra-purified water. Purified water was added up to the total volume of $50 \mathrm{~mL}$ in order to make $1 \mathrm{ppm}$ solution. A $0.5 \mathrm{~mL}$ of $1 \mathrm{ppm}$ solution was then diluted with $49.5 \mathrm{~mL}$ of purified water to make $0.01 \mathrm{ppm} .1 \mathrm{~mL}$ and $0.1 \mathrm{~mL}$ of 0.01 ppm solution were diluted with ultra-purified water for a total volume of $1 \mathrm{~L}$ to obtain final concentrations of $10 \mathrm{ng} \mathrm{L}^{-1}$ and the $1 \mathrm{ng} \mathrm{L}^{-1}$, respectively. The solutions were placed in a 1 $\mathrm{L}$ glass bottle capped with a glass stopper and equilibrated for a minimum of $24 \mathrm{~h}$ before the experiment. This working solution was used to identify the effects of light wavelength and DOC concentration on DGM formation, which is explained in detail below.

\subsubsection{Wavelength experiment}

A glass bottle filled with $1 \mathrm{~L}$ of working solution (Hg concentration $=10 \mathrm{ng} \mathrm{L}^{-1}$ ) was placed in a water bath (JSWV-06T) to maintain a constant temperature of $24^{\circ} \mathrm{C}$ inside of the chamber, which was made of a black acrylic panel in order to prevent the light from entering. Inside the chamber, UV-A (320-380 nm), UV-B (280-320 nm), and UV-C (200-280 nm) lamps were fixed on the wall and electric lines were connected to the on/off switches outside of the chamber through the hole (Fig. 1). The intensities

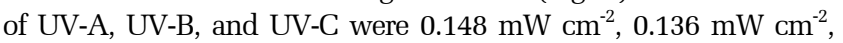
and $0.054 \mathrm{~mW} \mathrm{~cm}^{-2}$, respectively. Before starting the irradiation, the working solution was purged with zero-Hg air in the dark until the $\mathrm{Hg}$ concentration became close to or less than the background concentration (1-1.5 $\mathrm{pg} \mathrm{L}^{-1}$ ). Once $\mathrm{Hg}$ readings under dark conditions dropped to less than the background concentration, the lamps were turned on. Each lamp was on for 2 $\mathrm{h}$, off for 1 hour, and on again for $2 \mathrm{~h}$, which was maintained to be consistent for all experiments. Two hours of irradiation and one hour of darkness were chosen as independent variables in our experimental setup because the irradiation time was not a controlling factor to be tested in this study. Since large variations in DGM concentrations can occur over short timeframes, DGM

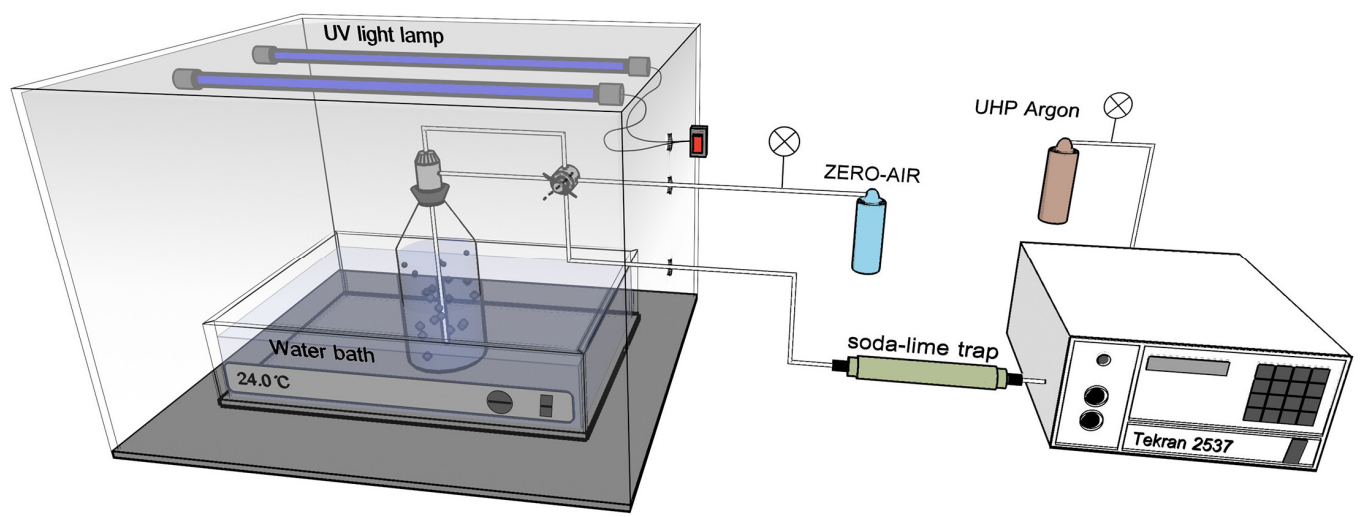

Fig. 1. Schematic design of the experimental setup for identifying the effects of light wavelength and dissolve organic carbon (DOC) concentration on dissolved gaseous mercury (DGM) production. 
concentrations were continuously measured every 5 min using a Tekran 2537B throughout the experiments.

\subsubsection{DOC experiment}

In order to identify the effect of DOC concentration on DGM formation, different amounts of humic acid sodium salt (Aldrich Cas-No.: 68131-04-4) were dissolved in the purified water to obtain four different DOC concentrations ranging from 0 to 4 $\mathrm{mg} \mathrm{L}^{-1}$. DOC concentrations in the working solutions were quantified using a TOC analyzer (Sievers 5310 C, GE, USA). Each sample was analyzed three or four times and the average DOC concentrations were $0,1,2.38$, and $3.92 \mathrm{mg} \mathrm{L}^{-1}$. Relative standard deviations (RSD) were 1.0, 3.8, and $0.5 \%$ for DOC concentrations of $1,2.38$, and $3.92 \mathrm{mg} \mathrm{L}^{-1}$, respectively. $\mathrm{Hg}$ concentration in the working solution was set to be $1 \mathrm{ng} \mathrm{L}^{-1}$ for this experiment.

DGM concentrations in the working solutions with different DOC concentrations were continuously measured under both dark conditions and UV-B irradiation. Samples were purged by ultra-high-purity air under the dark condition until DGM concentration became less than the background concentration, at which time the UV-B lamp was turned on again for $90 \mathrm{~min}$.

\subsection{DGM Analysis}

To measure DGM, $1 \mathrm{~L}$ of working solution was placed into a $1 \mathrm{~L}$ glass bottle capped with a glass stopper with inlet and outlet tubes. A zero-air tank was connected to the glass inlet tube with a Teflon stopcock to purge the solutions at a flow rate of $1.5 \mathrm{~L} \mathrm{~min}^{-1}$. Stripped DGM was withdrawn into the outlet tube connected to a Tekran 2537B to continuously measure DGM concentration; values were logged every five minutes (Fig. 1). A soda-lime trap was placed between the glass bottle and Tekran 2537B to remove water vapor and possible impurities that could possibly inhibit the detection of the Tekran instrument. A glass bottle with working solution was placed in a thermostatic water bath (JSWB-06T) to maintain a constant temperature of $24^{\circ} \mathrm{C}$ inside a black acrylic chamber throughout the experiment.

Tekran 2537B is a cold vapor atomic fluorescence spectrometry (CVAFS). Inside a Tekran 2537B, there are two gold cartridges where $\mathrm{Hg}$ vapor is collected. The gathered $\mathrm{Hg}$ was thermally desorbed at $525^{\circ} \mathrm{C}$ and carried by an ultra-high-purity argon stream into a detector and excited by light at a wavelength of $253.7 \mathrm{~nm}$. The excited atoms fluoresce at the same wavelength which was detected by a photomultiplier tube. The signal was converted to a voltage which was relayed to a computer.

In order to check whether there was any leakage in the sampling line, a stopcock was situated as the dotted line in Fig. 1 so that ultra-high-purity air was introduced into the Tekran 2537B (Fig. 1). It was determined that there was no leakage if the flow rate shown in Tekran 2537B was less than $0.05 \mathrm{~L}$ $\min ^{-1}$ when a ultra-high-purity air regulator was closed off.

\section{3. $Q A / Q C$}

The Tekran 2537B was calibrated using an internal permeation source before each experiment. Manual injections were also used to evaluate the automated calibration using a saturated mercury vapor standard. A certain volume of $\mathrm{Hg}$ saturated air $(0,10$,
20, 30, and $50 \mu \mathrm{L}$ ) was withdrawn by a gas tight syringe (Hamilton) from a closed flask containing about 2-3 $\mathrm{mL}$ of metallic mercury and injected into the manual injection port of the Tekran 2537B. The flask was maintained at $16.6^{\circ} \mathrm{C}$ by being immersed in a temperature-regulated water bath. Injected mercury mass was calculated from the temperature dependent density and the volume of Hg-saturated air withdrawn, and a calibration curve was obtained for both cartridges $\left(R^{2}>0.9995\right)$. The relative percent difference between the manual injection and automated calibration was less than $2 \%$. A recovery rate $(94 \pm 3 \%)$ was obtained by directly injecting $\mathrm{Hg}$ vapor into the Teflon tubing line between the ultra-high-purity air cylinder and the Tekran 2537B.

Cleaning procedures were in alignment with the United States Environment Protection Agency's method 1631E [33]. All Teflon and glass parts were first heated in $4 \mathrm{M} \mathrm{HCl}$ at $65-75^{\circ} \mathrm{C}$ for at least $48 \mathrm{~h}$ and then filled with $1 \% \mathrm{HCl}$ solution at $60-70^{\circ} \mathrm{C}$ in an oven overnight.

\section{Results and Discussion}

\subsection{Effect of UV Wavelength on DGM Formation}

To identify the effect of UV wavelength, a working solution of 10 ng-Hg L ${ }^{-1}$ was used. The working solution was purged with ultra-high-purity air in the dark until the DGM concentration became less than $1.5 \mathrm{pg} \mathrm{L}^{-1}$ before starting the irradiation. As soon as the UV lights were applied, DGM concentrations abruptly increased for all 3 conditions (i.e., UV-A, UV-B, and UV-C), but the increments were different (Fig. 2). In the experiment with UV-A, DGM concentrations rapidly increased, reached a plateau at approximately $5.6 \mathrm{pg} \mathrm{L}^{-1}$ within $20 \mathrm{~min}$, and then maintained for $2 \mathrm{~h}$ until the termination of UV-A irradiation. When the UV-A lamp was off, DGM concentrations immediately dropped to $1 \mathrm{pg} \mathrm{L}^{-1}$ within $15 \mathrm{~min}$, and as soon as UV-A lamp was turned on again, it increased instantaneously. As soon as UV-B irradiated, DGM concentration also immediately increased to around $30 \mathrm{pg} \mathrm{L}^{-1}$, which is approximately 5 times higher than the increment with UV-A irradiation, and started exponentially decreasing to $12 \mathrm{ng} \mathrm{L}^{-1}$ (Fig. 2). This occurrence was likely due to the decreasing amount of reducible $\mathrm{Hg}$.

When the UV-C lamp was switched to on, DGM concentrations also reached a peak of around $5 \mathrm{pg} \mathrm{L}^{-1}$ within $10 \mathrm{~min}$ and then gradually decreased during the $1^{\text {st }} 2$-h irradiation; however, during the second 2-h irradiation experiment, DGM slowly increased, which was not observed in the experiments with UV-A and UV-B (Fig. 2). In addition, under the dark condition in between two UV-C irradiation sessions, DGM did not drop as much as it did in the UV-A and UV-B experiments. The somewhat different results from UV-C irradiation may indicate that UV-C promotes the production of reducible $\mathrm{Hg}$ as well as $\mathrm{Hg}$ reduction. Not all the divalent $\mathrm{Hg}$ is in a reducible form, and the size of the reducible fraction is dependent on the incident wavelengths [34]. Previous research suggested that more reducible Hg was observed under radiation of shorter wavelengths of UV (UV-B rather than UV-A) [9]; however, there are not, as yet, any studies that have investigated the effect of UV-C on a fraction of reducible 


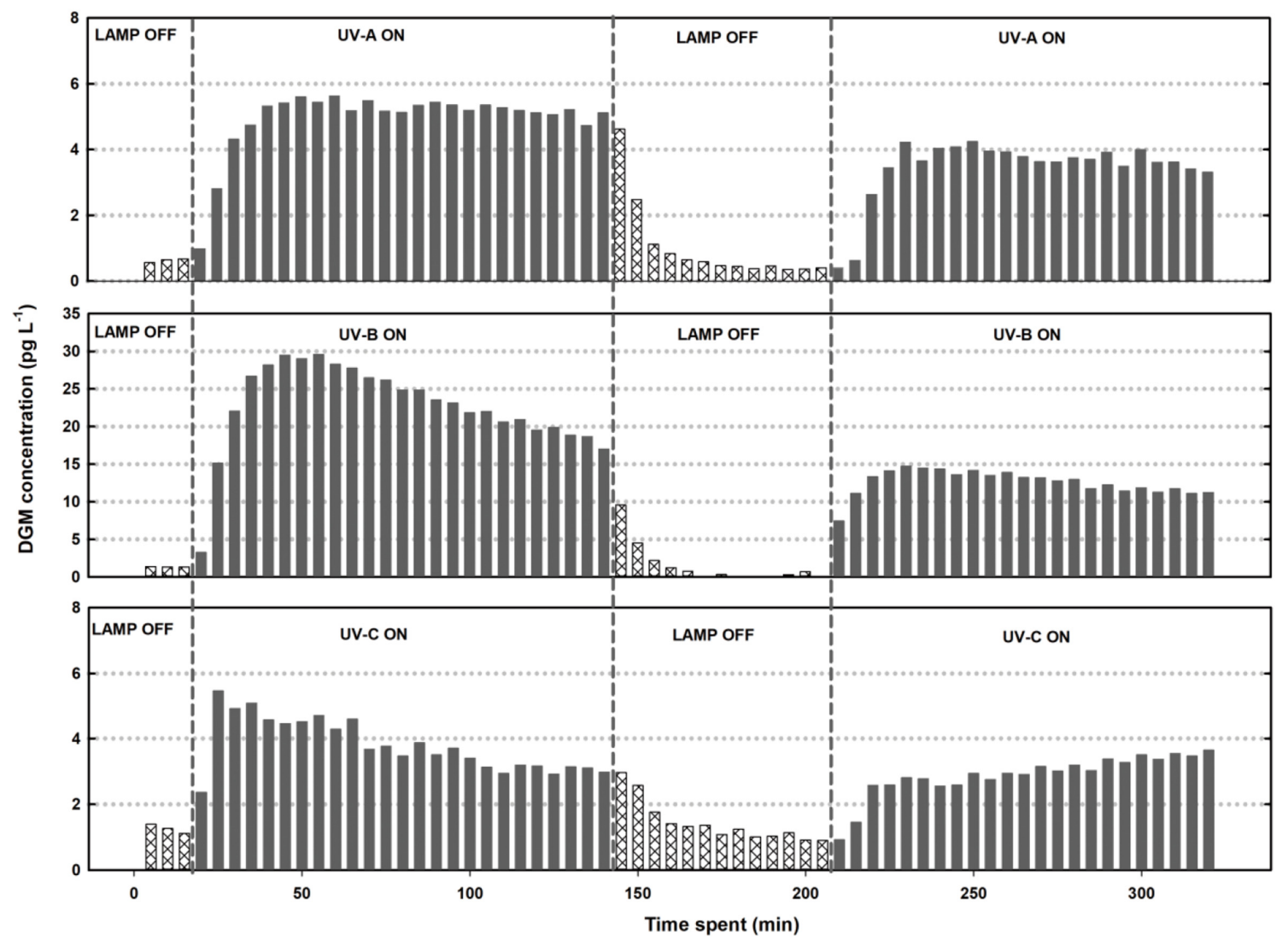

Fig. 2. Changes in dissolved gaseous mercury (DGM) concentrations every 5 min during irradiation of different wavelengths of UV light.

$\mathrm{Hg}$ in water. There are a few studies investigating the effect of wavelength of light on $\mathrm{Hg}$ emissions from soil surface. Park et al. [35] found that $\mathrm{Hg}$ emission from soil surface increased under UV-A and UV-B radiation because UV radiation wavelengths directly reduced $\mathrm{Hg}^{2+}$ to $\mathrm{Hg}^{0}$ in the soil surface. However, they also found that $\mathrm{Hg}$ was rather deposited onto the soil surface with UV-C exposure, indicating that atmospheric $\mathrm{Hg}^{0}$ was oxidized to $\mathrm{Hg}^{2+}$ in the air, followed by being deposited to the soil. Choi and Holsen [36] also observed that atmospheric Hg was oxidized with UV-C exposure. Although these previous results cannot be directly compared with our experiments aimed at $\mathrm{Hg}$ reduction in water, UV-C seems to have oxidative capacity, which can possibly generate the reducible $\mathrm{Hg}$ (II) in water. In this experiment using a three-wave lamp (visible light), DGM formation was not observed, which indicates that only UV is involved in $\mathrm{Hg}$ reduction mechanisms (Fig. S1).

In this experiment, DGM formed in the sample was continuously removed by purging with ultra-high-purity air to prevent the back-reduction; therefore, it followed the kinetics of gross reduction, that is, the reaction

$$
H g_{r}(I I)+\text { photo }- \text { reductants } \stackrel{k_{r}}{\longrightarrow} D G M
$$

where $\mathrm{Hg}_{\mathrm{r}}$ (II) indicates the reducible $\mathrm{Hg}$ in the sample. Assuming pseudo-first order kinetics, the following equations apply:

$$
\begin{gathered}
\frac{d\left[H g_{r}(I I)\right]}{d t}=-k_{r}\left[H g_{r}(I I)\right] \\
\frac{d[D G M]}{d t}=k_{r}\left[H g_{r}(I I)\right]
\end{gathered}
$$

DGM formation rates $(d[D G M] / d t)$ were compared for different wavelength lamps. The DGM formation rate was the highest for UV-B, followed by UV-A and UV-C (Table 1). Since the light intensity was different for the UV-A, UV-B, and UV-C lamps used in this study $\left(0.147 \mathrm{~mW} \mathrm{~cm}^{-2}, 0.136 \mathrm{~mW} \mathrm{~cm}^{-2}\right.$, and 0.054 $\mathrm{mW} \mathrm{cm}^{-2}$ for UV-A, UV-B, and UV-C, respectively), the DGM formation rates considering the light intensity $\left(\mathrm{pg}-\mathrm{Cm}^{2} \mathrm{~L}^{-1}-\mathrm{J}^{-1}\right)$ were also compared. The results indicated that the highest DGM formation rate was for UV-B, followed by UV-C and UV-A (Fig. 3). During the first $2-\mathrm{h}$ and the second $2-\mathrm{h}$ irradiations, the total DGM production amounts were 201.2, 840.5, and $161.9 \mathrm{pg}$ for UV-A, for UV-B, and UV-C, respectively (Table 1). Because the irradiation time was limited to $4 \mathrm{~h}$ for each UV light, the total possible production amount of DGM via a photo-reduction mechanism was not identified in this study. It will be worthwhile to conduct a similar experiment in the future until no further $\mathrm{Hg}_{\mathrm{r}}(\mathrm{II})$ is available for reduction (which means no further DGM is produced) with a lower $\mathrm{Hg}(\mathrm{II})$ injection amount and longer irradiation time. 
Jae-In Lee et al.

Table 1. DGM Formation Rate and Cumulative Amounts of DGM Produced during Irradiation with UV-A, UV-B, and UV-C Lamps. Note That the Initial $\mathrm{Hg}(\mathrm{II})$ Concentration Was $10 \mathrm{ng} \mathrm{L}^{-1}$ in a Working Solution

\begin{tabular}{|c|c|c|c|c|c|}
\hline & \multirow{2}{*}{$\begin{array}{l}\text { Radiation intensity } \\
\qquad\left(\mathrm{mW} \mathrm{cm}^{-2}\right)\end{array}$} & \multicolumn{2}{|c|}{ 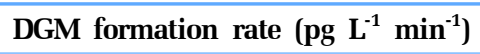 } & \multicolumn{2}{|c|}{ Cumulative DGM production (pg) } \\
\hline & & Irradiation- $^{\text {st }}$ & Irradiation-2 $^{\text {nd }}$ & Irradiation-1 $\mathbf{1}^{\text {st }}$ & Irradiation-2 ${ }^{\text {nd }}$ \\
\hline UV-A & 0.148 & $0.99 \pm 0.20$ & $0.69 \pm 0.18$ & 118.5 & 82.7 \\
\hline UV-B & 0.136 & $4.54 \pm 1.13$ & $2.52 \pm 0.32$ & 551.0 & 289.5 \\
\hline UV-C & 0.054 & $0.75 \pm 0.16$ & $0.60 \pm 0.13$ & 91.9 & 70.0 \\
\hline
\end{tabular}

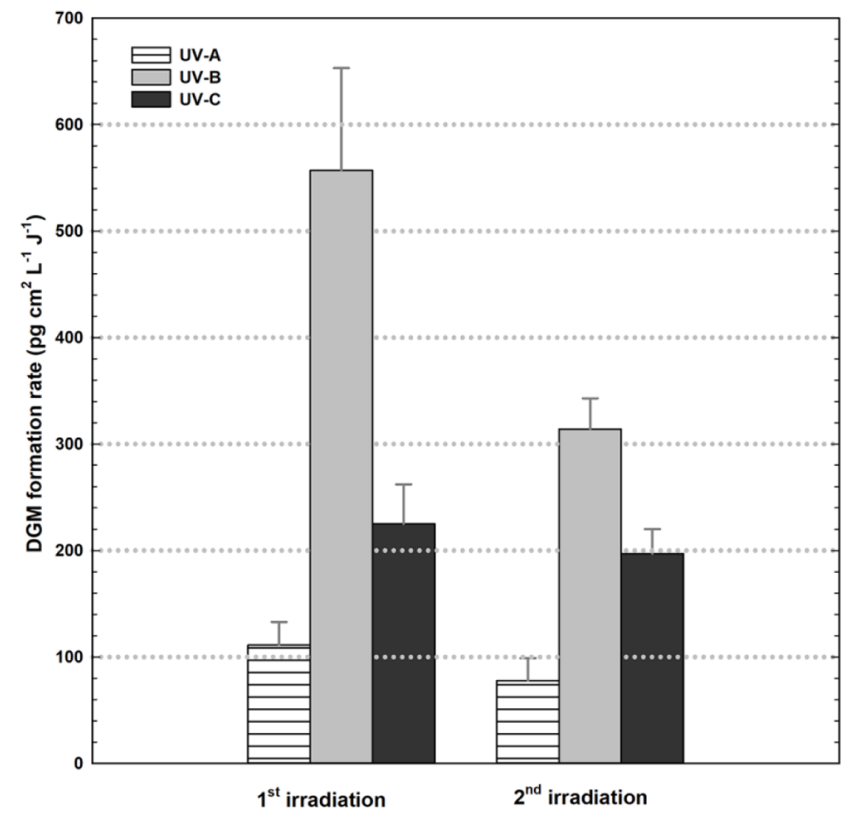

Fig. 3. Formation rate of dissolved gaseous mercury (DGM) normalized by light intensity during the first and second irradiation of UV-A, UV-B, and UV-C.

Because $\mathrm{Hg}_{\mathrm{r}}$ (II) can better absorb UV-B light rather than UV-A and UV-C lights, DGM formation was the highest with UV-B radiation. According to Nriagu [37], Hg compounds combined with ions and organocomplex can absorb the light of 270-400 nm wavelengths which corresponds to UV-A and UV-B. Other studies also suggested that DGM formation under UV-B light was the highest when compared with those for UV-A [38-39]. According to Garcia et al. [22], about $61-73 \%$ of total photo-induced DGM was reduced by UV radiation and only approximately $27 \%$ was produced by visible light. Amyot et al. [40] also found that maximum DGM levels produced under visible and UV radiation (UV-A + UV-B) were twice the amount of formed DGM by visible light alone in a controlled laboratory experiment. Increased DGM formation under all UV radiation was clearly observed in our study; however, DGM did not show an identifiable increment under visible light.

\subsection{Effect of DOC Concentration on DGM Formation}

\subsubsection{DGM formations under dark condition}

$\mathrm{Hg}$ reduction was studied under various DOC concentrations including $0.0,1.0,2.4$, and $3.9 \mathrm{mg} \mathrm{L}^{-1}$. DGM concentrations were continuously measured in the dark condition during the 90 min prior to UV-B irradiation. DGM concentration decreased and reached a plateau within $40 \mathrm{~min}$ for $0.0,1.0,2.4$, and 3.9 $\mathrm{mg} \mathrm{L}^{-1}$ of DOC concentration. After DGM reached a plateau, average DGM formation rates were calculated, and they were $0.12 \pm 0.02,0.22 \pm 0.05,0.40 \pm 0.10$, and $0.53 \pm 0.03 \mathrm{pg}$ $\mathrm{L}^{-1} \mathrm{~min}^{-1}$ for $0.0,1.0,2.4$, and $3.9 \mathrm{mg} \mathrm{L}^{-1}$ of DOC concentrations in the working solution, respectively (Table 2). Increasing DGM formation rates with increasing DOC concentration suggests that DOC facilitates Hg reduction even without light and without microbial activity. Previous researches proposed that $\mathrm{Hg}^{2+}$ could be directly reduced by humic substances via ligand metal charge transfer [31, 35, 41]. Alberts et al. [42] also reported that $\mathrm{Hg}^{2+}$ could be directly reduced by humic substances under the assumption that quinone or semiquinone moieties in organic matter were involved in the transfer of electrons that led to $\mathrm{Hg}$ reduction.

\subsubsection{DGM formations under UV-B radiation}

DOC is often acknowledged to be important in the photo-reduction of $\mathrm{Hg}[14,25,43-44]$. In order to identify the effect of DOC concentrations on DGM photo-production, UV-B was irradiated on the samples with various DOC concentrations (0.0, 1.0, 2.4, and, $3.9 \mathrm{mg} \mathrm{L}^{-1}$ ) and DGM concentrations were continuously tracked. The initial $\mathrm{Hg}(\mathrm{II})$ concentration was $1 \mathrm{ng} \mathrm{\textrm {L } ^ { - 1 }}$. All samples were purged with ultra-high-purity air for $90 \mathrm{~min}$ under the dark condition before UV-B irradiation. UV-B was selected instead of UV-A or UV-C since it exhibited the highest DGM production among three different wavelengths of UV (Fig. 2). As

Table 2. Different DGM Concentrations and Formation Rates under Various DOC Concentrations in a Working Solution. Note That the Initial $\mathrm{Hg}$ (II) Concentration Was $1 \mathrm{ng} \mathrm{L}^{-1}$ in a Working Solution

\begin{tabular}{lccccc}
\hline & & & \multicolumn{2}{c}{ DOC concentrations (mg $\left.\mathbf{L}^{-1}\right)$} \\
\cline { 3 - 6 } & Condition & $\mathbf{0 . 0}$ & $\mathbf{1 . 0}$ & $\mathbf{2 . 4}$ & $\mathbf{3 . 9}$ \\
\hline DGM concentration within first $10 \mathrm{~min}\left(\mathrm{pg} \mathrm{L}^{-1}\right)$ & Dark & 82.70 & 41.22 & 32.41 & 38.70 \\
DGM formation rate $\left(\mathrm{pg} \mathrm{L}^{-1} \mathrm{~min}^{-1}\right)$ & Dark & $0.12 \pm 0.02$ & $0.22 \pm 0.05$ & $0.40 \pm 0.10$ & $0.54 \pm 0.03$ \\
& UV-B irradiation & $0.51 \pm 0.10$ & $1.16 \pm 0.18$ & $1.37 \pm 0.46$ & $1.58 \pm 0.29$ \\
\hline
\end{tabular}


soon as the UV-B lamp was on, DGM concentrations instantly increased for all samples; although, the increments were different. DGM formation rates clearly increased as DOC concentrations increased from 0 to $3.9 \mathrm{mg} \mathrm{L}^{-1}$ (Table 2), which suggested a positive effect of DOC concentrations on DGM formation with UV-B irradiation. According to previous studies [14, 45-46], DOC absorbed solar radiation and emitted electrons which reduced $\mathrm{Hg}$, as in Eq. (4) and (5). In addition, photolysis of DOC can form reactive reductants, such as $\mathrm{HO}_{2} \bullet$, that reduces $\mathrm{Hg}(\mathrm{II})$ [47-48].

$$
\begin{gathered}
{[D O C]+h v \rightarrow\left[D O C^{\cdot+}\right]+e^{-}(a q)} \\
2 e^{-}(a q)+\left[H^{2+}\right] \rightarrow\left[H g^{0}\right]
\end{gathered}
$$

If all DOC in the sample was photolyzed, the production of electron and DGM would increase logarithmically as DOC concentration increased. The relationship between DGM formation rate and DOC concentration was found to be more likely to follow the logarithmic equation than the linear equation, as shown in Table 2; however, it is not conclusive due to the insufficient sample number and future work is worthwhile to be conducted with a wide range of DOC concentration.

Many previous studies [24, 49-50] found a similar result that DGM formation by lights increased in the presence of fulvic and humic acid. However, there are also several other studies demonstrating a negative effect of DOC on $\mathrm{Hg}$ reduction. Amyot et al. [29] observed lower DGM production in high DOC lakes and Watras et al. [26] found that an increasing DOC concentration was related to an exponential decrease in the DGM/TM ratio. In the laboratory work by Garcia et al. [22], there was a strong positive correlation between DGM production and DOC concentration under UV-A radiation whereas DGM production was negatively correlated with UV-B radiation. The contradictory results were likely caused by differing conditions. In this study, DGM production was traced under the gross reduction condition that was maintained by continuously stripping formed DGM from the samples. However, Hg reduction and oxidation concurrently occurred in the most reference studies [22, 26, 29, 49], which suggests that DOC and UV-B might affect oxidation as well as reduction mechanisms.

\subsection{Rate Constants for $\mathrm{Hg}$ Reduction}

Using Eq. (6) and (7), the rate constant for gross reduction, $k_{r}$ could be calculated from the experimental data. It was assumed that the initial concentration of $\mathrm{Hg}_{\mathrm{r}}$ (II) was equal to the total injected $\mathrm{Hg}$ in the working solutions. Differential equations were solved numerically, as follows.

$$
\begin{gathered}
\frac{\left[H g_{r}(I I)\right]_{t+\Delta t}-\left[H g_{r}(I I)\right]_{t}}{\Delta t}=-k_{r}\left[H g_{r}(I I)\right]_{t} \\
\frac{[D G M]_{t+\Delta t}-[D G M]_{t}}{\Delta t}=k_{r}\left[H g_{r}(I I)\right]_{t}
\end{gathered}
$$

When UV light was on, the DGM amount produced during unit time $(d[D G M] / d t)$ started to increase, reached a plateau within
$25 \mathrm{~min}$, and then maintained relatively consistent production during the first irradiation period (Fig. 2). In this study, $k_{r}$ was averaged based on the DGM production rate shown during the plateau section. The reduction constants, $k_{r}$ were $1.9 \times 10^{-6}$ $\mathrm{s}^{-1}, 8.6 \times 10^{-6} \mathrm{~s}^{-1}$, and $1.4 \times 10^{-6} \mathrm{~s}^{-1}$ for UV-A, UV-B, and UV-C, respectively (Fig. 4).

The reduction constants were also identified under various DOC concentrations. Without UV radiation, $k_{r}$ ranged from 2.2 $\times 10^{-6} \mathrm{~s}^{-1}$ to $9.7 \times 10^{-6} \mathrm{~s}^{-1}$ (upper panel of Fig. 4), showing that $k_{r}$ increased as DOC increased even under the dark condition. Please note that the total $\mathrm{Hg}$ injected in the working solutions was $10 \mathrm{ng} \mathrm{L}^{-1}$ in the experiments with UV wavelengths (lower panel of Fig. 4); whereas, it was $1 \mathrm{ng} \mathrm{L}^{-1}$ in the experiment with DOC (upper panel of Fig. 4). Under the irradiation of UV-B, $k_{r}$ also noticeably increased as DOC increased. The reduction constants were $1.0 \times 10^{-5} \mathrm{~s}^{-1}, 2.4 \times 10^{-5} \mathrm{~s}^{-1}, 2.7 \times 10^{-5} \mathrm{~s}^{-1}$, and $3.5 \times 10^{-5} \mathrm{~s}^{-1}$ for $0.0,1.0,2.4$, and $3.9 \mathrm{mg} \mathrm{L}^{-1}$ of DOC concentrations, respectively. The rate of increase on $k_{r}$ was the most evident when DOC increased from 0 to $1 \mathrm{mg} \mathrm{L}^{-1}$, and then subsided afterwards, although $k_{r}$ continued to increase. The highest DOC concentration was set to $3.9 \mathrm{mg} \mathrm{L}^{-1}$ in this study because DOC typically ranges from 1 to $4 \mathrm{mg} \mathrm{L}^{-1}$ in most of the reservoirs in Korea [51-54]. A slowdown in the rate of increase in $k_{r}$ indicates that there may be a different relationship between DGM production

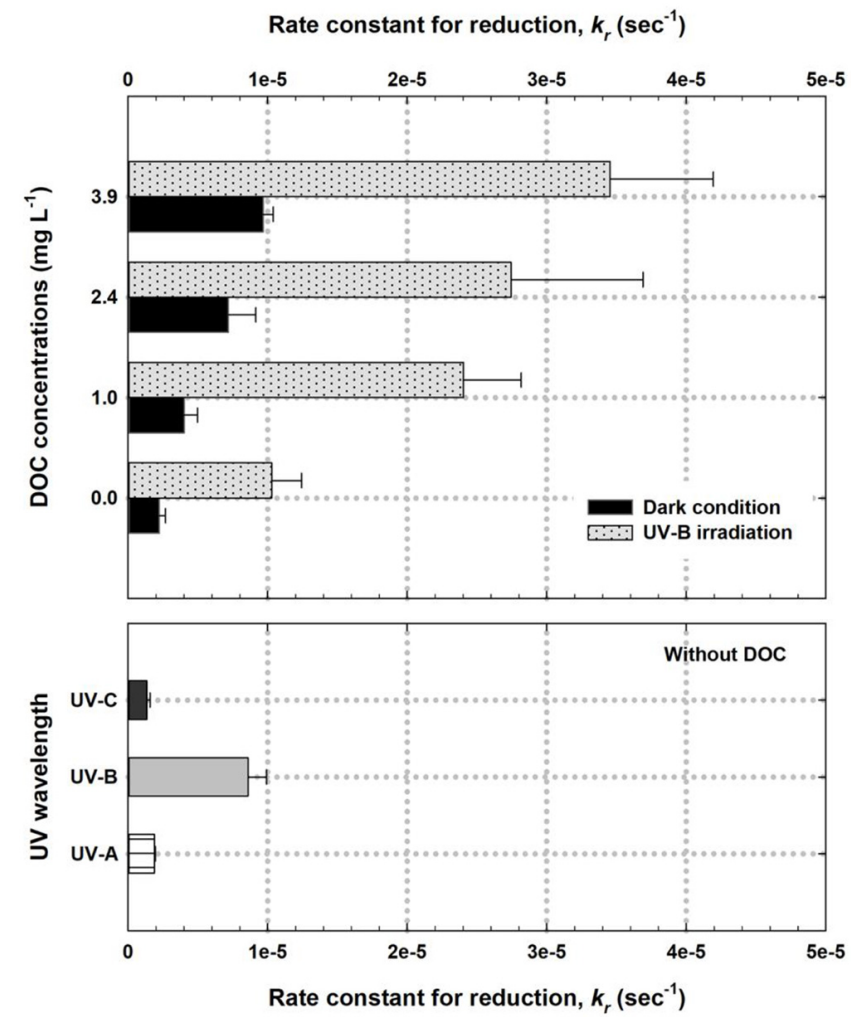

Fig. 4. Rate constants for $\mathrm{Hg}$ reduction with four different concentrations of dissolved organic carbon (DOC) under the dark condition and UV-B irradiation (upper panel) and with irradiation of UV-A, UV-B, and UV-C without DOC (lower panel).

and DOC concentration at higher ranges of DOC concentration. 
In fact, a good number of studies [22, 26, 29] that utilized DOC concentrations that were in a much higher range than in this study, demonstrated a negative relationship between DGM concentration (or production) and DOC concentration.

The reduction rate constant reported by other studies varied from $1.7 \times 10^{-6} \mathrm{~s}^{-1}$ [55] to $1.2 \times 10^{-3} \mathrm{~s}^{-1}$ [56] in seawater and from $7.76 \times 10^{-5}$ [39] to $2.9 \times 10^{-4} \mathrm{~s}^{-1}$ [56] in freshwater. These values were obtained from seawater or freshwater in which microorganisms were present; whereas, ultra-purified water was used in this study. Therefore, the somewhat lower $k_{r}$ obtained in this study was anticipated because microbial reduction did not occur. In addition, $k_{r}$ is dependent on the UV light intensity [39, 57], so it cannot be simply compared without the consideration of light intensity. In the studies conducted by Qureshi et al. [58] and Soerensen et al. [59], $k_{r}$ was expressed as $\alpha I$, where $\alpha$ is a constant $\left(\mathrm{m}^{2} \mathrm{~s}^{-1} \mathrm{~W}^{-1}\right)$ and $I$ is the UV light intensity $\left(\mathrm{W} \mathrm{m}^{-2}\right.$ ). In this study, the slopes, $\alpha$ were calculated to be 1.3 $\times 10^{-6}, 6.3 \times 10^{-6}$, and $2.5 \times 10^{-6} \mathrm{~m}^{2} \mathrm{~s}^{-1} \mathrm{~W}^{-1}$ for UV-A, UV-B, and UV-C without DOC, respectively, which were similar to the value $\left(1.7 \times 10^{-6} \mathrm{~m}^{2} \mathrm{~s}^{-1} \mathrm{~W}^{-1}\right)$ proposed by Soerensen et al. [59]. With the existence of DOC, $\alpha$ ranged from $7.4 \times 10^{-6}$ to $3.5 \times 10^{-5} \mathrm{~m}^{2} \mathrm{~s}^{-1} \mathrm{~W}^{-1}$ under UV-B radiation, which was a slightly higher range than the values reported by Soerensen et al. [59]. It should be noted that the work by Soerensen et al. [59] used seawater and that the $\mathrm{Hg}$ photoreduction tends to be inhibited by the presence of chlorides, which may compete with organic matter for binding with $\mathrm{Hg}[31,58]$.

\section{Conclusions}

Many previous studies have investigated the influencing factors on $\mathrm{Hg}$ reduction mechanisms in aquatic environments; however, most studies were conducted in natural environments such as lakes and oceans where reduction and oxidation simultaneously occur. In this study, DGM formation was studied under different UV wavelengths and DOC concentrations in a controlled environment. DGM formation significantly increased with irradiation of all UV lights even without DOC; whereas, there was no noticeable increase of DGM production with visible light. The DGM formation rate was the highest for UV-B, which indicated that Hg can better absorb UV-B light rather than UV-A and UV-C lights. With DOC concentrations of 0.0, 1.0, 2.4 and $3.9 \mathrm{mg} \mathrm{L}^{-1}$, DGM formation increased as DOC concentration increased even under the dark condition, which demonstrated that divalent $\mathrm{Hg}$ can be directly reduced by DOC without light. When the UV-B irradiation started, DGM production was instantly enhanced and it increased as DOC concentration increased. The increment of DGM production was the highest when DOC increased from 0 to $1 \mathrm{mg} \mathrm{L}^{-1}$ and slowed down afterwards, which suggests that DGM production may not be linearly correlated with DOC concentration at higher ranges of DOC. This possibility could be a reason why many previous studies found conflicting results for the relationship between DGM and DOC concentrations. In addition, the DOC structure and composition can also affect the DGM production rate [12, 21]. DGM production should be tracked over a broad range of DOC concen- trations with different DOC structures in future studies to identify the effect of DOC.

The calculated rate constants for reduction $\left(k_{r}\right)$ in this study ranged from $1.4 \times 10^{-6} \mathrm{~s}^{-1}$ to $3.5 \times 10^{-5} \mathrm{~s}^{-1}$ with the lower values occurring under the dark condition without DOC and the higher values resulting under the UV-B radiation with high DOC concentration condition. Even without DOC present, DGM was undoubtedly produced under UV radiation, which is contradictory to the findings by Allard and Arsenie [27] that $\mathrm{Hg}$ must be complexed with DOC for photoreduction to occur. The $k_{r}$ calculated in this study was placed in a somewhat lower range than those obtained from seawater and freshwater in previous studies because microbial reduction did not occur.

\section{Acknowledgments}

This work was funded by a National Research Foundation of Korea (NRF) grant funded by the Korean government (MSIP) (Grant No. 2015R1A2A203008301) and by the Korea Ministry of Environment (MOE) as part of the "Environmental Health Action Program” (2015001370001).

\section{References}

1. Nriagu JO. Biogeochemistry of mercury in the environment. Elsevier/North-Holland Biomedical Press; 1979.

2. Schroeder WH, Munthe J. Atmospheric mercury - An overview. Atmos. Environ. 1998;32:809-822.

3. O'Driscoll N, Poissant L, Canario J, Ridal J, Lean D. Continuous analysis of dissolved gaseous mercury and mercury volatilization in the upper St. Lawrence River: Exploring temporal relationships and UV attenuation. Environ. Sci. Technol. 2007;41:5342-5348.

4. $\mathrm{Hu} \mathrm{H}$, Lin $\mathrm{H}$, Zheng $\mathrm{W}$, et al. Oxidation and methylation of dissolved elemental mercury by anaerobic bacteria. Nature Geosci. 2013;6:751-754.

5. UNEP: The global atmospheric mercury assessment. UNEP Chemical Branch, Geneva, Switzerland; 2013.

6. Stein ED, Cohen Y, Winer AM. Environmental distribution and transformation of mercury compounds. Crit. Rev. Environ. Sci. Technol. 1996;26:1-43.

7. Ullrich SM, Tanton TW, Abdrashitova SA. Mercury in the aquatic environment: A review of factors affecting methylation. Crit. Rev. Environ. Sci. Technol. 2001;31:241-293.

8. Fitzgerald WF, Lamborg CH, Hammerschmidt CR. Marine biogeochemical cycling of mercury. Chem. Rev. 2007;107:641-662.

9. Liu G, Cai Y, O'Driscoll N. Environmental chemistry and toxicology of mercury. John Wiley \& Sons; 2011.

10. Siciliano SD, O'Driscoll NJ, Lean D. Microbial reduction and oxidation of mercury in freshwater lakes. Environ. Sci. Technol. 2002;36:3064-3068.

11. Schaefer JK, Letowski J, Barkay T. mer-mediated resistance and volatilization of $\mathrm{Hg}(\mathrm{II})$ under anaerobic conditions. Geomicrobiol. J. 2002;19:87-102.

12. Kelly C, Rudd JW, Holoka M. Effect of $\mathrm{pH}$ on mercury uptake 
by an aquatic bacterium: Implications for Hg cycling. Environ. Sci. Technol. 2003;37:2941-2946.

13. Amyot M, Southworth G, Lindberg S, et al. Formation and evasion of dissolved gaseous mercury in large enclosures amended with ${ }^{200} \mathrm{HgCl}_{2}$. Atmos. Environ. 2004;38:4279-4289.

14. O'Driscoll N, Lean D, Loseto L, Carignan R, Siciliano S. Effect of dissolved organic carbon on the photoproduction of dissolved gaseous mercury in lakes: Potential impacts of forestry. Environ. Sci. Technol. 2004;38:2664-2672.

15. Tseng C, Lamborg C, Fitzgerald W, Engstrom D. Cycling of dissolved elemental mercury in Arctic Alaskan lakes. Geochim. Cosmochim. Acta 2004;68:1173-1184.

16. Barkay T, Wagner-Döbler I. Microbial transformations of mercury: Potentials, challenges, and achievements in controlling mercury toxicity in the environment. Adv. Appl. Microbiol. 2005;57:1-52.

17. Wiatrowski HA, Ward PM, Barkay T. Novel reduction of mercury(II) by mercury-sensitive dissimilatory metal reducing bacteria. Environ. Sci. Technol. 2006;40:6690-6696.

18. Amyot M, Auclair J, Poissant L. In situ high temporal resolution analysis of elemental mercury in natural waters. Anal. Chim. Acta 2001;447:153-159.

19. Zhang H, Lindberg SE. Trends in dissolved gaseous mercury in the Tahquamenon River watershed and nearshore waters of Whitefish Bay in the Michigan Upper Peninsula. Water Air Soil Pollut. 2002;133:381-391.

20. O'Driscoll NJ, Beauchamp S, Siciliano SD, Rencz AN, Lean DR. Continuous analysis of dissolved gaseous mercury (DGM) and mercury flux in two freshwater lakes in Kejimkujik Park, Nova Scotia: Evaluating mercury flux models with quantitative data. Environ. Sci. Technol. 2003;37:2226-2235.

21. Dill C, Kuiken T, Zhang H, Ensor M. Diurnal variation of dissolved gaseous mercury (DGM) levels in a southern reservoir lake (Tennessee, USA) in relation to solar radiation. Sci. Total Environ. 2006;357:176-193.

22. Garcia E, Amyot M, Ariya PA. Relationship between DOC photochemistry and mercury redox transformations in temperate lakes and wetlands. Geochim. Cosmochim. Acta 2005;69:1917-1924.

23. Ahn M, Kim B, Holsen TM, Yi S, Han Y. Factors influencing concentrations of dissolved gaseous mercury (DGM) and total mercury (TM) in an artificial reservoir. Environ. Pollut. 2010;158:347-355.

24. Xiao Z, Strömberg D, Lindqvist O. Influence of humic substances on photolysis of divalent mercury in aqueous solution. Water Air Soil Pollut. 1995;80:789-798.

25. O'Driscoll N, Siciliano S, Peak D, Carignan R, Lean D. The influence of forestry activity on the structure of dissolved organic matter in lakes: Implications for mercury photoreactions. Sci. Total Environ. 2006;366:880-893.

26. Watras CJ, Morrison KA, Host JS, Bloom NS. Concentration of mercury species in relationship to other site-specific factors in the surface waters of northern Wisconsin lakes. Limnol. Oceanogr. 1995;40:556-565.

27. Soerensen AL, Mason RP, Balcom PH, Sunderland EM. Drivers of surface ocean mercury concentrations and air-sea exchange in the West Atlantic Ocean. Environ. Sci. Technol.
2013;47:7757-7765.

28. Larson RA, Marley KA. Oxidative mechanisms of phototoxicity. In: Nriagu JO, Simmons MS, eds. Oxidants in the environment. Advances in environmental science and technology. New York: J. Wiley and Sons; 1994. p. 269-317.

29. Amyot M, Mierle G, Lean D, Mc Queen DJ. Effect of solar radiation on the formation of dissolved gaseous mercury in temperate lakes. Geochim. Cosmochim. Acta 1997;61:975-987.

30. Maloney KO, Morris DP, Moses CO, Osburn CL. The role of iron and dissolved organic carbon in the absorption of ultraviolet radiation in humic lake water. Biogeochemistry 2005;75:393-407.

31. Allard B, Arsenie I. Abiotic reduction of mercury by humic substances in aquatic system - An important process for the mercury cycle. Water Air Soil Pollut. 1991;56:457-464.

32. Park J, Oh S, Shin M, Kim M, Yi S, Zoh K. Seasonal variation in dissolved gaseous mercury and total mercury concentrations in Juam Reservoir, Korea. Environ. Pollut. 2008;154:12-20.

33. EPA U. Method 1631, Revision E: Mercury in water by oxidation, purge and trap, and cold vapor atomic fluorescence spectrometry. US Environmental Protection Agency Washington, DC; 2002.

34. Gu B, Bian Y, Miller CL, Dong W, Jiang X, Liang L. Mercury reduction and complexation by natural organic matter in anoxic environments. Proc. Natl. Acad. Sci. USA 2011;108: 1479-1483.

35. Park SY, Holsen TM, Kim PR, Han YJ. Laboratory investigation of factors affecting mercury emissions from soils. Environ. Earth Sci. 2014;72:2711-2721.

36. Choi HD, Holsen TM. Gaseous mercury emissions from unsterilized and sterilized soils: The effect of temperature and UV radiation. Environ. Pollut. 2009;157:1673-1678.

37. Nriagu JO. Mechanistic steps in the photoreduction of mercury in natural waters. Sci. Total Environ. 1994;154:1-8.

38. Oh S, Kim M, Lee Y, Zoh K. Effect of Abiotic and biotic factors on the photo-induced production of dissolved gaseous mercury. Water Air Soil Pollut. 2011;220:353-363.

39. O'driscoll N, Siciliano S, Lean D, Amyot M. Gross photoreduction kinetics of mercury in temperate freshwater lakes and rivers: Application to a general model of DGM dynamics. Environ. Sci. Technol. 2006;40:837-843.

40. Amyot M, Lean DR, Poissant L, Doyon M. Distribution and transformation of elemental mercury in the St. Lawrence River and Lake Ontario. Can. J. Fish. Aquat. Sci. 2000;57: 155-163.

41. Spokes LJ, Liss PS. Photochemically induced redox reactions in seawater, I. Cations. Mar. Chem. 1995;49:201-213.

42. Alberts JJ, Schindler JE, Miller RW, Nutter DE Jr. Elemental mercury evolution mediated by humic Acid. Science 1974;184:895-897.

43. Matthiessen A. Kinetic aspects of the reduction of mercury ions by humic substances. Fresenius J. Anal. Chem. 1996;354:747-749.

44. Matthiessen A. Reduction of divalent mercury by humic substances - Kinetic and quantitative aspects. Sci. Total Environ. 1998;213:177-183. 
45. Cooper WJ, Zika RG, Petasne RG, Fischer AM. Sunlight-induced photochemistry of humic substances in natural waters: Major reactive species. In: Anonymous: ACS Publications; 1989.

46. Zepp RG, Braun AM, Hoigne J, Leenheer JA. Photoproduction of hydrated electrons from natural organic solutes in aquatic environments. Environ. Sci. Technol. 1987;21:485-490.

47. Voelker BM, Morel FM, Sulzberger B. Iron redox cycling in surface waters: Effects of humic substances and light. Environ. Sci. Technol. 1997;31:1004-1011.

48. Zhang H, Lindberg SE. Sunlight and iron(III)-induced photochemical production of dissolved gaseous mercury in freshwater. Environ. Sci. Technol. 2001;35:928-935.

49. Costa M, Liss P. Photoreduction of mercury in sea water and its possible implications for $\mathrm{Hg}^{0}$ air-sea fluxes. Mar. Chem. 1999;68:87-95.

50. Ravichandran M, Araujo R, Zepp R. Role of humic substances on the photochemical reduction of mercury. Am. Chem. Soc. 2000;220:U362-U362.

51. Kim B, Choi K, Kim C, Lee U, Kim Y. Effects of the summer monsoon on the distribution and loading of organic carbon in a deep reservoir, Lake Soyang, Korea. Water Res. 2000;34:3495-3504.

52. Choi K, Kim B, Lee U. Characteristics of dissolved organic carbon in three layers of a deep reservoir, Lake Soyang, Korea. Int. Rev. Hydrobiol. 2001;86:63-76.
53. Park H, Byeon M, Shin Y, Jung D. Sources and spatial and temporal characteristics of organic carbon in two large reservoirs with contrasting hydrologic characteristics. Water Resour. Res. 2009;45.

54. Lee Y, Hur J, Shin K. Characterization and source identification of organic matter in view of land uses and heavy rainfall in the Lake Shihwa, Korea. Mar. Pollut. Bull. 2014;84:322-329

55. Whalin L, Kim E, Mason R. Factors influencing the oxidation, reduction, methylation and demethylation of mercury species in coastal waters. Mar. Chem. 2007;107:278-294.

56. Whalin LM, Mason RP. A new method for the investigation of mercury redox chemistry in natural waters utilizing deflatable Teflon ${ }^{\circledR}$ bags and additions of isotopically labeled mercury. Anal. Chim. Acta. 2006;558:211-221.

57. Bash JO, Cooter EJ. Bidirectional mercury exchange over surface waters simulated by a regional air pollution model. 10th Conference on Atmospheric Chemistry. 2008.

58. Qureshi A, O’Driscoll NJ, MacLeod M, Neuhold Y, Hungerbü hler K. Photoreactions of mercury in surface ocean water: Gross reaction kinetics and possible pathways. Environ. Sci. Technol. 2009;44:644-649.

59. Soerensen AL, Sunderland EM, Holmes CD, et al. An improved global model for air-sea exchange of mercury: High concentrations over the North Atlantic. Environ. Sci. Technol. 2010;44:8574-8580 